\title{
PACITAN DISTRICT GOVERNMENT POLICY IMPLEMENTATION IN THE SUGAR COCONUT INDUSTRY PROMOTION AND DEVELOPMENT ON FTA
}

\author{
Supomo $^{1}$, Eko Ganis Sukoharsono ${ }^{2}$, Wike $^{3}$, and Endah Setyowati ${ }^{4}$ \\ ${ }^{1}$ Postgraduate Doctor of Environmental Sciences, Brawijaya University \\ ${ }^{2}$ Professor of Environmental Accounting, Universitas Brawijaya \\ ${ }^{3}$ Department of Public Administration, Faculty of Administrative Sciences, Universitas \\ Brawijaya \\ ${ }^{4}$ Department of Public Administration, Faculty of Administrative Sciences, Universitas \\ Brawijaya
}

\begin{abstract}
The importance of the industry based on coconut sugar for the people in Pacitan Regency has an important value, so that the function and role of the government is very much needed to increase the existing coconut sugar industry. The purpose of this study was to analyze the potential of coconut sugar SMEs in Pacitan District, analyze the constraints in the development of coconut sugar SMIs and analyze the role of local governments in facilitating coconut sugar SMEs. Retrieval of data in this study includes field observations, document studies and interviews with all stakeholders such as coconut sugar industry players, consumers, Micro Cooperative and Business Services and the Pacitan Regency Industry and Trade Office. Data analysis techniques use interactive analysis. Pacitan Regency is one of the best coconut sugar producing regions in Indonesia with a total of brown sugar industry which is as many as 5,115 units. This sugar industry can absorb 10,220 workers or $39.03 \%$ of the workforce in Pacitan Regency. This is due to the large number of raw materials in the area of Pacitan Regency. The
\end{abstract}


coconut sugar industry is currently experiencing two obstacles in its production process and marketing. The Micro Cooperative and Business Office and the Pacitan Regency Industry and Trade Office in order to increase coconut sugar SMIs carry out coaching and facilitation. The guidance and facilitation includes training, work equipment facilities, product legality facilities, promotional facilities and capital facilities.

Keywords: facilitation, coconut sugar, IKM, constraints 


\section{INTRODUCTION}

In the framework of implementing the free market, Indonesia has participated in many Free Trade Area (FTA) trade agreement agreements. Various international trade agreements will create fierce competition and healthy competitiveness (Suharsih and Sriwinarti, 2012). As of September 2017, 10 international economic agreements have been signed from 21 negotiations conducted by Indonesia. As many as 2 agreements are made bilaterally and 6 are agreements in the context of Indonesia as a member of ASEAN. Every economic region where FTAs are carried out has unequal trade opportunities and challenges (Sukoharsono, 2006).

The implementation of free trade agreements has consequences for product competitiveness, both competitiveness in the international market and competitiveness in the domestic market. In addition, Indonesia's participation in the FTA is a threat as well as a market opportunity for potential local products in regions in Indonesia (Ridhwan and Nurliana, 2015), including IKM products in Pcitan Regency. Free trade free trade can have a negative impact on local agricultural-based SMEs. The high price of local agricultural commodities causes competition from outside commodities that enter freely into Indonesia. The next condition is the decline of small industries in Indonesia (Sukoharsono, 2006).

An alternative strategy that can be done in an effort to deal with free trade is to create and produce superior products that are not the result of assistance from other countries, so that these goods have a strong bargaining position in the global economy (Satryo, 2018). Modernization that emphasizes economic growth with high technology and large capital needs to be transformed into development with insight into product locality. In industries with sensitivity, this locality does not require advanced technology that is controlled by developed countries instead of appropriate and adaptive technology with the surrounding area(Aubert, 2005). The development of product locality or decentralization system has a pretty good meaning in national development because each region will be able to develop the superior potential of each region and use a development approach characterized by locality and develop local knowledge(Ahmad et al., 2005). 
One industry that is local and has the advantage of this product is the coconut sugar (brown sugar) industry. Indonesia is the second largest exporter of coconut sugar in the world. Coconut sugar products are widely exported to various countries such as the United States, Belgium, China, the Netherlands, France, Chile, Brazil, Taiwan, South Korea and so on. One of the best coconut sugar producers in Indonesia is Pacitan Regency. Pacitan Regency has a potential potential for coconut sugar industry. Sugar products from Pacitan do not use dangerous substance ingredient (Indonesia Trade Promotion Centre, 2017).

The importance of the industry based on coconut sugar for the people in Pacitan Regency has an important value, so that the function and role of the government is very much needed to increase the existing coconut sugar industry. This is in accordance with the mandate of the 1945 Constitution regarding the government's commitment and legal policy towards the economic and social rights of the people. The economic and social rights of the people are in the form of the right to try to create conditions, which allows each individual or society to be free in making their choices. In addition, the state guarantees the availability of goods in realizing public welfare as mandated in the opening and torso of the 1945 Constitution (Kemenperin, 2018).

The purpose of this research is in order to analyze the potecy of Small and Medium Industries (SMI) coconut Sugar, analyzing the various constraints that exist and analyze the role of government in fostering SMI coconut sugar in Pacitan. 


\section{METHODOLOGY}

\section{Time and Place}

This research was conducted in Pacitan Regency, East Java Province. Pacitan Regency is a center for coconut sugar industry.

Figure 1. Map of Pacitan Regency

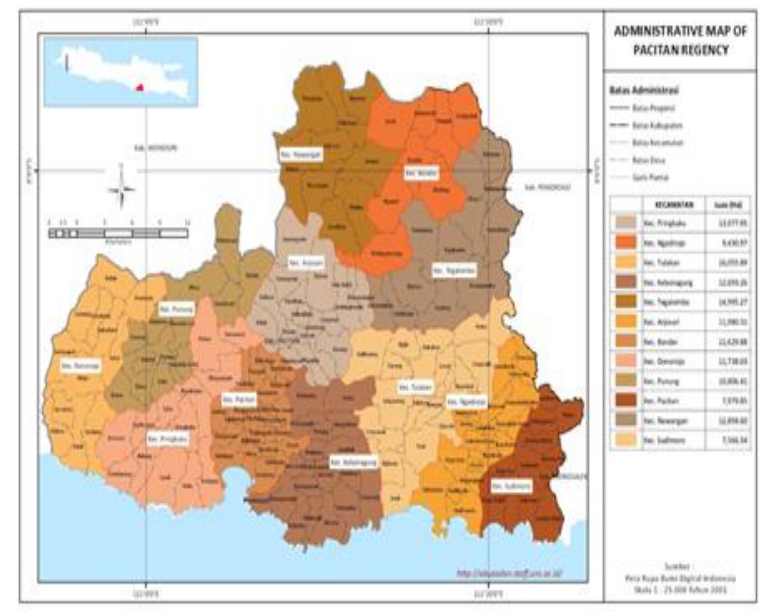

\section{How to Work}

Retrieval of data in this study includes field observations, document studies and interviews with all stakeholders such as coconut sugar industry players, consumers, Micro Cooperative and Business Services and the Pacitan Regency Industry and Trade Office. Field observations were used to find out the coconut sugar industrial activities carried out by the community and the training activities carried out by the tertiary service with the SMI. Document studies are used to find out the potential of Pacitan district in the coconut sugar industry. Interviews with stakeholders are used to know the programs of the Pacitan district government in order to develop the coconut sugar industry.

\section{Data Analysis}

The data analysis technique used in this study is interactive analysis. This model has 4 components of analysis, namely: data collection, data reduction, data presentation, and conclusion drawing. 


\section{RESULTS AND DISCUSSION}

\section{Potential of coconut sugar in Pacitan Regency}

Palm Sugar products, in international trade are classified with HS 1702.90 Sugar Nes (including Invert Sugar). Although the production in the country is differentiated according to the type of tree as its source, namely coconut sugar and palm sugar, but in international trade only one type is known, namely Coconut Sugar or Coconut Palm Sugar (Indonesia Trade Promotion Centre, 2017)

Pacitan Regency is one of the best coconut sugar producing regions in Indonesia and has potential in developing this industry. According to data from the Department of Industry and Trade, the number of industries in Pacitan Regency in 2017 was 23,323 companies. The processing industry in Pacitan Regency is mostly the brown sugar industry, which is 5,115 units. This sugar industry can absorb 10,220 workers or $39.03 \%$ of the workforce in Pacitan Regency. This is due to the large number of raw materials in the area of Pacitan Regency. In Pacitan district coconut plantations are the largest with a planting area of around 23,510 hectares with yields reaching 21,053.40 tons / year when compared to other industries (Hilmanto, 2013).

Table 1. Industrial Types in Pacitan Regency

\begin{tabular}{|c|c|c|c|c|}
\hline \multirow[b]{2}{*}{ No } & \multirow[b]{2}{*}{ Industrial Types } & \multirow{2}{*}{$\begin{array}{l}\text { Number of } \\
\text { units a }\end{array}$} & $\begin{array}{c}\text { Human } \\
\text { resources }\end{array}$ & $\begin{array}{c}\text { Production } \\
\text { values }\end{array}$ \\
\hline & & & (man power) & $(\mathbf{x} 1,000$ IDR $)$ \\
\hline 1 & gems stone) & 416 & 535 & $12,450,000$ \\
\hline 2 & Brown sugar & 5,115 & 10,220 & $55,242,000$ \\
\hline 3 & Batik & 15 & 621 & $9.246,000$ \\
\hline 4 & Processed fish & 186 & 377 & $32,164,000$ \\
\hline 5 & Earthenware & 84 & 109 & $1,750,000$ \\
\hline 6 & Wood Processing & 997 & 3,049 & $319,065,000$ \\
\hline 7 & Processed Cassava & 315 & 530 & $8,420,000$ \\
\hline
\end{tabular}




\begin{tabular}{|c|l|c|c|c|}
\hline 8 & Woven & 527 & 1,092 & $4,990,000$ \\
\hline 9 & Other Processed Foods & 2,487 & 4,896 & $136,188,100$ \\
\hline 10 & Creative & 1,721 & 3,649 & $108,233,100$ \\
\hline \multicolumn{2}{|c|}{ TOTAL } & 11,863 & 25,078 & $687,738,200$ \\
\hline
\end{tabular}

\section{Obstacles to the development of the coconut sugar industry}

The coconut sugar industry is currently experiencing two obstacles in its production process and marketing. The coconut sugar production process is still traditionally carried out nowadays there are no tools or infrastructure to support industrial activities such as equipment to package products so that they have high selling prices and are able to compete besides there is also no analysis of their products including nutritional analysis and pathogenic microorganisms. In terms of marketing the coconut sugar industry depends on the presence of middlemen.

\section{Regional Government Policy in improving the Coconut Sugar industry}

In accordance with the vision, mission and program of the Regional Head and Deputy Regional Head to provide an overview of the role and direct involvement of the Department of Industry and Trade in Pacitan Regency. This is shown through: Mission statement "Building the community's economy by mobilizing regional potential supported by the availability of adequate infrastructure". In this mission, the Department of Industry and Trade has a role in realizing a competitive industry through the development program for small and medium industries, including the coconut sugar industry which is widely found in the Pacitan Regency area.

Especially to improve the quality of coconut sugar according to export standards, it is necessary to provide guidance to the coconut sugar industry players, considering that only standard sugar products are acceptable in the international market. The guidance carried out by the Micro, Cooperative and Business Office and the Department of Industry and Trade in Pacitan Regency is guidance and facilitation. The guidance and facilitation includes training, work equipment facilities, product legality facilities, promotional facilities and capital facilities 
To improve the performance of SMIs in Pacitan District, the Pacitan Industry and Trade Service conducts trainings. The training is through training in processing raw materials, processing raw materials and selling. The existence of this training led to the diversification of pacitan coconut sugar products which not only produced round-shaped shell sugar or sugar but also produced ant sugar which was in the form of powder and had more durability. In addition, the facilitation of training has caused many industries to start hygienic packaging of the products they produce

The existence of work equipment in supporting industrial activities is important. This caused the Pacitan District Government through the Office of Trade and Industry to provide support by providing work equipment assistance. Based on the Pacitan Regency Public Relations document data, the assistance that has been given is a large crater or pan as a place to heat sugar raw materials

Product legality facilities are important in an industry including the small insudtri in Pacitan. Product legality in the form of making halal certificates and Intellectual Property Rights (IPR). In making a halal certificate the terms are the identity of the business owner, PKP certificate and P-IRT. While for IPR besides the identity card of the business owner, there is also a sample of the brand that wants to be patented. Product legality efforts are a form of protection against coconut sugar SMIs from brand copyers. In addition, the product legality will make it easier for coconut sugar products from Pacitan to expand products outside the region.

The Department of Industry and Trade of Pacitan Regency in order to increase the marketing reach of coconut sugar products is one of them by providing promotional facilitation. Promotions in the form of exhibitions, trade missions, and e-commerce. The exhibition aims to provide solutions to marketing problems that have always been the problem of coconut sugar SMIs by including coconut sugar products. With the exhibition, it is expected that IKM can have the ability to develop products based on their respective market share.

The existence of small businesses, requires support from various parties, especially the support of capital. For small entrepreneurs mengah coconut sugar sugar capital facilitation opens the opportunity to be able to start a business or develop a business that already has. Decentralization and regional autonomy policies in 2001, local 
governments have great authority to plan, formulate and implement development policies and programs that are in accordance with local needs (Law of the Republic of Indonesia Number 32 of 2004 concerning Regional Government). This government is responsible for empowering small industries in the region with the help of rotating capital.

To improve the quality and quantity of sustainable coconut sugar in Pacitan Regency, coconut sugar SMI are recommended for:

$=$ Entrepreneurs of SMI coconut sugar are willing to change the traditional mindset to more advanced ones according to market demands

$=$ Coconut sugar SMI entrepreneurs need to form a group that can support their business, so that $\mathrm{ikm}$ products can meet the standards both in terms of quality and quantity of production

$=$ The Need for Diversification of coconut sugar products and processing into derivative products

$=$ Entrepreneurs of SMI coconut sugar conduct certification of their coconut trees into organic, chemical-free for the export market.

In addition, for policy makers in this case the local government of Pacitan Regency, the matters recommended are as follows

$=$ efforts to improve the quality of coconut sugar in pacitan by the local government continue to be carried out with various training facilitation activities and production equipment for SMI coconut sugar entrepreneurs

$=$ Mentoring for coconut sugar SMI entrepreneurs continues, so that SMI entrepreneurs can apply good and correct production processes

$=$ Access to infrastructure for the ikm area must be improved so that transportation is easy

$=$ Expansion of coconut sugar SMI centers, considering that all Pacitan areas are suitable for coconut plants

$=$ The need for regeneration Coconut plants belong to coconut sugar SMI entrepreneurs, considering that currently there are an average age of $>40$ years 


\section{CONCLUSION}

Based on the results of the study, it can be concluded as Pacitan Regency is one of the best coconut sugar producing regions in Indonesia, in Pacitan Regency in 2017 there were 5,115 sugar industry units with 10,220 workers or 39.03\% workers in Pacitan Regency. The coconut sugar industry is currently experiencing two obstacles in its production process and marketing. Department of Cooperatives and Micro and the Department of Trade and Industry Pacitan in order to develop SMIs palm sugar in the form of facilitation. Coaching and facilitation, covering training, facilities, work equipment, capital facilitation, facilitation of legality, facilities promotion / marketing. Of 5 facilitation has been done by the Government in fostering SMI palm sugar, it should be added 2 facilitation namely the facilitation of the legality of operations and facilitating the supply of raw materials, namely coconut tree planting in all areas of Pacitan and open up new SME centers, 


\section{REFERENCES}

Ahmad, J. et al. (2005) 'Decentralization and Service Delivery', Handbook of Fiscal Federalism. doi: 10.4337/9781847201515.00018.

Aubert, J.-E. (2005) 'Promoting Innovation in Developing Countries: A Conceptual Framework'. doi: 10.1596/1813-9450-3554.

Hilmanto, R. (2013) 'Tinjauan Resolusi Kebijakan Publik Tentang Pembiayaan Usaha Kehutanan dan Pertanian Dalam Menghadapi Perdagangan Bebas (AC-FTA) dan Krisis Global', Jurnal Administrasi Publik, 4(2).

Indonesia Trade Promotion Centre (2017) 'Peluang ekspor produk gula palem di pasar kanada', Market Brief edisi 2017.

Kemenperin (2018) 'Daya Saing Indonesia', pp. 1-11.

Ridhwan, M. M. and Nurliana, L. (2015) 'Working Paper Analysis of Competitiveness and National Strategic Industries in the Era of the Asean Economic Community and Free Trade'.

Satryo, C. (2018) 'Free Trade Intervention: Political-Economic Intervention on Global Business Environment', Asia Pacific Management and Business Application, 007(01), pp. 31-44. doi: 10.21776/ub.apmba.2018.007.01.3.

Suharsih, S. and Sriwinarti, A. (2012) 'Daya Saing Produk Ekspor Di Era Perdagangan Bebas', Jurnal Ekonomi dan Studi Pembangunan, 13(1), pp. 1-11.

Sukoharsono, E. G. (2006) 'Alternatif Riset Kualitatif Sains Akuntansi : Biografi, Phenomenologi, Grounded Theory, Critical Ethnografi dan Case Study', Analisis Makro dan Mikro: Jembatan Kebijakan Ekonomi Indonesia, pp. 230245. 